\title{
THE DYNAMICS OF THE AUSTRALIAN \\ INDUSTRIAL PROPERTY MARKET
}

\author{
Jinu Kim \\ University of New South Wales
}

\begin{abstract}
This paper aims to analyse the dynamics of the Australian industrial property market in terms of the economic and location factors between 1984 and 2002. The focus is to look at the cyclical patterns of Australian industrial property investment performance. This paper investigates the economic and location factors of the Australian industrial property market with investment performance index (total return). The sector specific economic factors of Australian industrial property market started to decline after more than 10 years positive growth between 1991 and 2002. The Sydney industrial property market was under negative location factors from 2001. The Melbourne industrial property market started to grow with positive location factors from 2001. The Brisbane industrial property market was under negative location factors since 1996.
\end{abstract}

Keywords: Australian industrial property market, sector specific economic factor, location factor.

\section{INTRODUCTION}

It is generally accepted that the factors affecting the values of properties are the economic, location and property factors. This paper explores how the Australian industrial property market has performed from 1984 to 2002 in response to the economic and location factors. The Investment Performance Index (IPI) by the Property Council of Australia (PCA) was used in order to assess the performance of Australian industrial property market in terms of the economic and location factors. It is assumed that the total returns of the Australian property market may show the effects of economic factors. This paper investigates the effect of sector specific economic factors upon the total return of the Australian industrial property market, and the location factors in the Sydney, Melbourne and Brisbane industrial property markets.

\section{FACTORS THAT INFLUENCE THE VALUES OF PROPERTIES}

Factors that have major effects upon values of the existing stock of properties are identified as the economic factors, the location factors and the property factors. 
The economic factors refer to the economic conditions as a wide range of aspects at the national level, while the location factors refer to location aspects at the regional level. Finally, the property factors describe the characteristics of property itself, such as the buildings and the land belonging to it.

The economic factors embrace the location factors; and the location factors embrace the property factors. The classification of these factors is mainly based on the coverage of the areas. The economic conditions are concerned with macroeconomic matters such as the state of the national economy, the state of the financial market and the changes of taxation. The location aspects are concerned with micro-economic matters such as the local demand and supply, the planning and development policies of the region, and changes in charges and fees. The characteristics of property itself are the functional aspects of the property, the aesthetic aspects of the buildings, and the physical aspects of the land and buildings.

These three types of factors arise out of the basic nature of properties such as longevity, immobility and heterogeneity. A property does not comprise only the brick, soil, columns, and physical features, but is defined as a bundle of privileges or benefits accruing to the owner for the period of the ownership. Because the stream of benefits produced from a property depends as much on factors external to the locus of the property itself, the value of a property depends to a considerable degree on the state of the economic base and the quality and type of location. This forces investment appraisal of property investment to focus on the economic and location factors rather than the property factors. This paper only focuses on the economic and location factors.

\section{Economic factors in the property market}

The property market is directly influenced by the general economic activity and economic situation of the country as a whole (Boykin and Ring, 1993: 68). The important indices of the economic conditions include Gross Domestic Product (GDP), per capita income and real wage levels, unemployment, personal savings and investments, and building and construction activities. Barrett and Blair (1989: 41-46) divide the economic factors on basis of their impact (or origin) into the demand and supply sides of the economy. The demand side of the economy includes population, total community income and distribution, and sources of employment. The supply side of the economy includes existing and planned supply of properties and competitive environment.

Barrett and Blair (1988: 243-244) describe the property market as being greatly affected by inflation. Property tends to increase in price because of the wellestablished re-sale market and the slow rates of depreciation compared to other assets. The prices of properties have generally increased more than the general price level (inflation). Expectation of future inflation is just as important as 
inflation, and many investors have been willing to accept fairly low rates of return in order to purchase a property, with the expectation of future inflation with rental growth and capital appreciation.

The property market is one of the first markets to be affected by rising interest rates (Barrett and Blair, 1988). Property market activities such as occupation, investment and development, are affected by changes in interest rate. Since a tight monetary policy - that is, high interest rates - normally slows down the economic growth and reduces demand, interest rates not only influence the demand for occupation, but also the supply of properties. Along with material and labour costs, high interest rates increase the costs of development because most developers borrow to build. Consequently, interest rates affect both the occupation and development property markets. The investment property market emphasises the capital values and the current yield rate as the key variables. The capital value of a property can be formulated with either yield rate or discount rate, which is closely related to interest rates. Interest rates then affect investment property markets as well. Thus, interest rates affect the occupation, investment and development markets in the property market.

Wofford (1983: 275) explains that property taxes have a tremendous impact on individuals and their decisions to own and improve property, and on the types and timing of development. If the property taxes have been substantially increased, the values of properties will probably fall. This adjustment will occur because the increased carrying costs associated with owning properties reduce the profits, which investors could expect from selling them in the future. When investors take the change in property taxes into account in deciding how much they can pay, they are said to capitalise those taxes into the values of properties. The changes in taxation therefore influence the values of properties. The economic factors therefore affect generally the performance of property markets.

\section{Location factors in the property market}

Because of characteristics of longevity and immobility in the nature of property, the value of a property is linked closely to the economic situation of the region in which it is located. The capital value of a property is estimated as the present worth of the expected future stream of incomes received from ownership of the property. As the expected future growth of a region declines, the value of the property may fall, even if there is no change in the current economic situation at the national level. Certainly, the development activities for new properties in the region will be affected. Indeed, differences in development activities among urban areas are so critical that it is almost always inappropriate to rely solely upon national trends to analyse current and future property prospects for a specific city. Consequently, a property market analysis must consider location aspects (Barrett and Blair, 1988: 183). 
Barrett and Blair (1988: 41-46) explain the location aspects as the indirect economic factors. The indirect economic factors include zoning, ground conditions and topography, utilities, transportation linkage and traffic, parking, environmental impact, impact on government services, and prevailing attitudes. These indirect economic factors (location factors) are major constraints to be overcome in the development market. The location factors are therefore the critical factors in the development market and the essential factors in the investment and occupation markets.

\section{CORRELATIONS BETWEEN THE ECONOMIC FACTORS AND THE AUSTRALIAN INDUSTRIAL PROPERTY MARKET}

This section analyses correlations between the investment performance of the industrial property market and the economic factors in the Australian industrial property market. The economic factors include the following variables; the inflation (CPI), the demand side of the economy (GDP, new capital expenditure on plant and equipment, the short-term interest rate), and the supply side of the economy (industrial building approvals and commencements). These variables (between 1984 and 2002, half yearly) are abbreviated as follows:

CPI: Consumer Price Index in the weighted average of 8 capital cities in Australia (Source; ABS)

GDP: Gross Domestic Product in Australia for half year (seasonally adjusted) (Source; ABS)

PNE: $\quad$ New capital expenditure on plant and equipment in Australia for half year (Source; RBA)

INT: $\quad$ Short-term interest rate as the yield of 90 day bank bills (an average for half year) (Source; RBA)

APV: $\quad$ Values of industrial building approvals in Australia for half year (Source; ABS)

CMC: $\quad$ Values of industrial building commencements in Australia for half year (Source; ABS).

Table 1 shows correlation coefficients between variables in the economic factors and the total return indices ${ }^{1}$ of Australian industrial property market (AUIND). The investment performance of the industrial property market (AUIND) has

\footnotetext{
${ }^{1}$ Source: Investment Performance Index (IPI) by the Property Council of Australia (PCA).
} 
significant positive correlations with the inflation (CPI), the demand side of the economy (GDP and PNE), while it has negative correlation with the interest rates (INT). However, the investment performance of the industrial property market has no noticeable correlations with the supply side of the economy (APV and CMC) compared with the demand side. It is concluded that the total return of the industrial property market is associated with the changes of the economic factors in the Australian industrial property market.

Table 1: Correlations between investment performance of Australian industrial property and economic variables: 1984-2002

\begin{tabular}{l|l|l|l|l|l|l|l}
\hline Variable & AUIND & CPI & GDP & PNE & INT & APV & CMC \\
\hline AUIND & 1.00 & $0.87^{*}$ & $0.98^{*}$ & $0.91^{*}$ & $-0.67^{*}$ & $0.52^{*}$ & $0.43^{*}$ \\
\hline
\end{tabular}

* significant at the 0.05 level

\section{EFFECTS OF ECONOMIC AND LOCATION FACTORS IN AUSTRALIAN INDUSTRIAL PROPERTY MARKET}

This section analyses the relative effects of economic and location factors on the total return of Australian industrial property markets. From the previous sections, the total returns of Australian property market show the effects of economic factors. Figure 1 shows the total returns of Australian composite property market and Australian industrial property market from 1984 to 2002. The Australian composite property market and Australian industrial property market have achieved positive total returns during the study period except between 1990 and 1993. It means that both markets are affected by positive economic factors during the study period except between 1990 and 1993

In order to assess the effect of sector specific economic factors upon the total return of Australian industrial property market, the total return of Australian property market was compared with the total return of Australian composite property market. The total return of Australian industrial property market is affected by the sector specific economic factors of the industrial property market. This can be illustrated as follows:

$$
\begin{aligned}
& T R A I_{t}=T R A C_{t} *(1+E F I) \\
& \text { where } T R A I_{t}=\text { total return of Australian industrial property market } \\
& \text { at time } t \\
& T R A C_{t}=\text { total return of Australian composite property market } \\
& \text { at time } t \\
& E F I=\text { specific economic factors of the industrial property } \\
& \text { market } \\
& \text { (Subscript }{ }_{t} \text { will be dropped in further equations.) }
\end{aligned}
$$


Figure 1: Total returns (half year) of Australian composite property and Australian industrial property: $1984-2002$

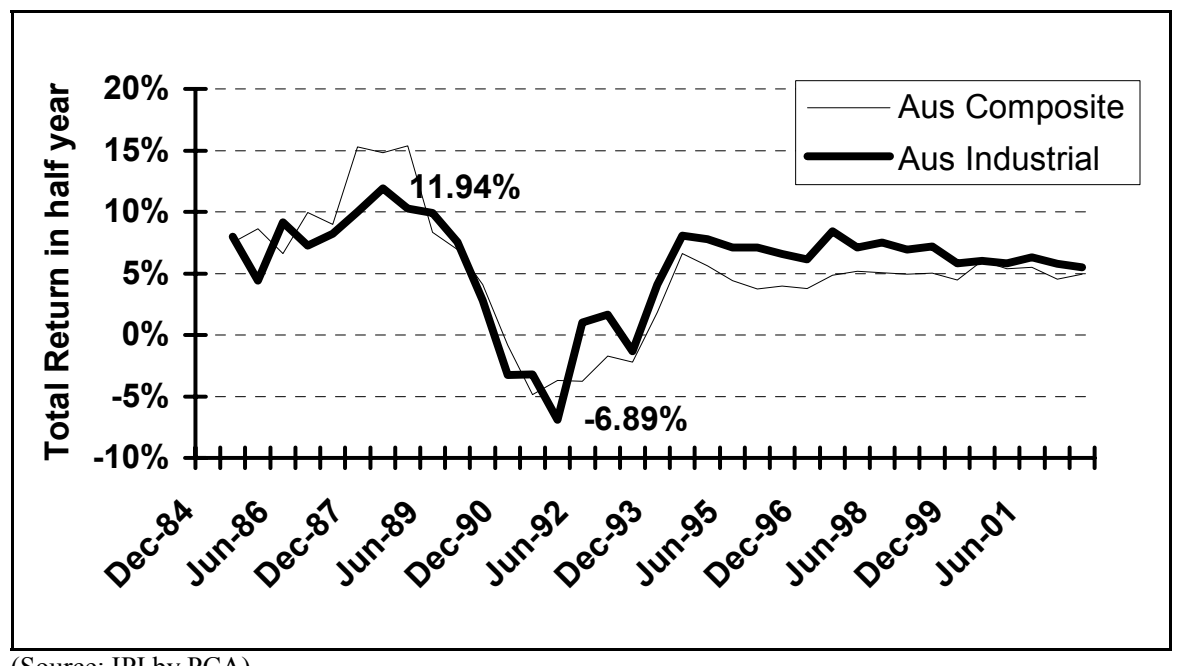

(Source: IPI by PCA)

From the above equation (1), the equation for the sector specific economic factors of the industrial property market can be rearranged as follows:

$$
\begin{aligned}
E F I & =T R A I / T R A C-1 \\
& =(T R A I-T R A C) /|T R A C|
\end{aligned}
$$

Figure 2 shows the sector specific economic factors ( $E F I)$ of Australian industrial property market from 1984 to 2002 according to the equation (2). As illustrated by the curve-linear trend line $^{2}$ in Figure 2, the Australian industrial property market shows positive sector specific economic factors from 1991 to 2002. However, it shows that the sector specific economic factors of the Australian industrial property market started to decline after more than 10 years positive growth.

${ }^{2}$ The curve-linear trendline was created by using the polynomial equation $\left(y=b+c_{1} x+c_{2} x^{2}\right)$. 
Figure 2: Sector specific economic factors (with a curve-linear trendline; poly) of Australian industrial property market: 1984 - 2002

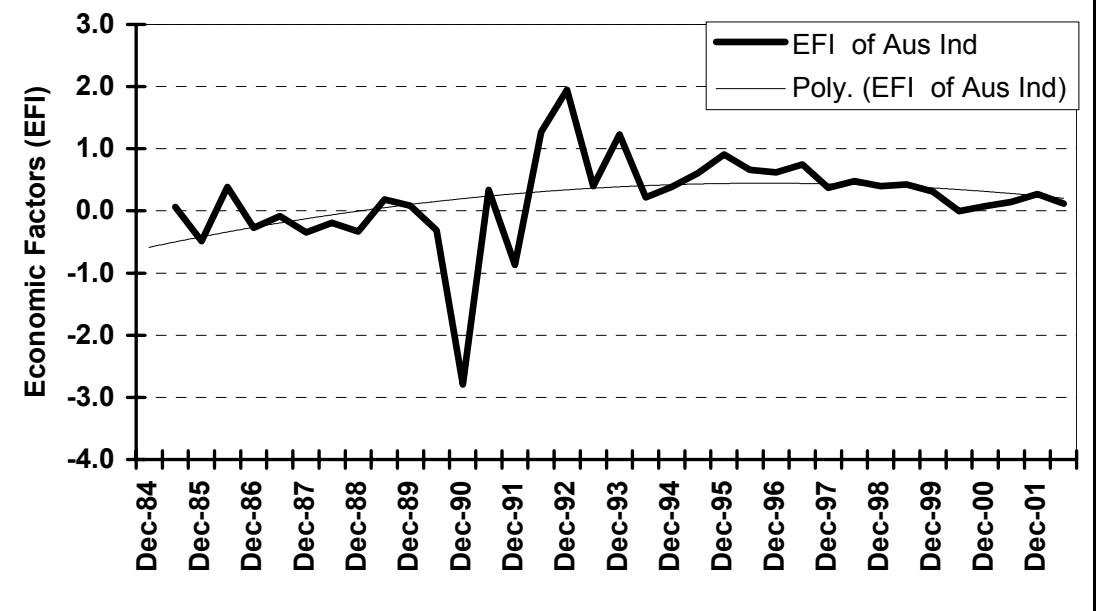

Since the values of industrial properties are affected by the economic and location factors in the industrial property market, the total return of an industrial property market is thus a function of the economic and location factors. This can be illustrated as follows:

$$
\begin{aligned}
& T R I a=T R A C *(1+E F I) *(1+L F a) \\
& =T R A I *(1+L F a)
\end{aligned}
$$

As described in the Table 1, the economic factors embrace the location factors. The effect of location factors upon the total return of industrial properties can be then calculated. From the above equation (3), the equation for the location factors can be rearranged as follows:

$$
\begin{aligned}
L F a & =T R I a / T R A I-1 \\
& =(T R I a-T R A I) /|T R A I|
\end{aligned}
$$


Using equation (4), the location factors in Sydney, Melbourne, and Brisbane industrial property markets are analysed in the following sections. The difference between the total return of the industrial property market in a particular capital city and the total return of Australian industrial property market is due to location factors.

Figure 3 shows the total returns of Australian, Sydney, Melbourne, and Brisbane industrial property markets from 1994 to 2002. Figures 4, 5, and 6 show the location factors of Sydney, Melbourne, and Brisbane industrial property markets from 1994 to 2002 respectively according to equation (4).

Figure 3: Total returns (half year) of Australian, Sydney, Melbourne, and Brisbane industrial property markets; $1994-2002$

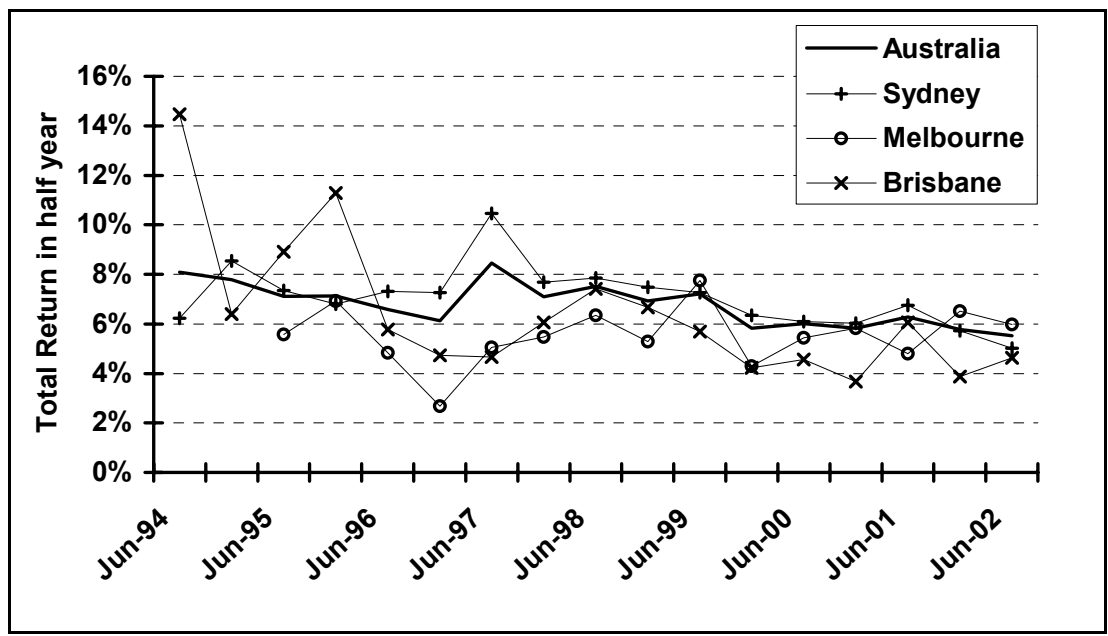

(Source: IPI by PCA)

As illustrated by the trend line in Figure 4, the Sydney industrial property market shows positive location factors from 1995 to 2000 . However, it shows that the location factors of the Sydney industrial property market became negative from 2001. As illustrated by the trend line in Figure 5, the Melbourne industrial property market shows negative location factors since 1994 to 2000 . However, it shows that the location factors of the Melbourne industrial property market started to grow and became positive location factors from 2001. As illustrated by the trend line in Figure 6 , the Brisbane industrial property market shows a sharp decline of location factors from 1994. It shows that the location factors of the Brisbane industrial property market became negative since 1996. 
Figure 4: Location factors (with a curve-linear trendline; poly) of Sydney industrial property market: $1994-2002$

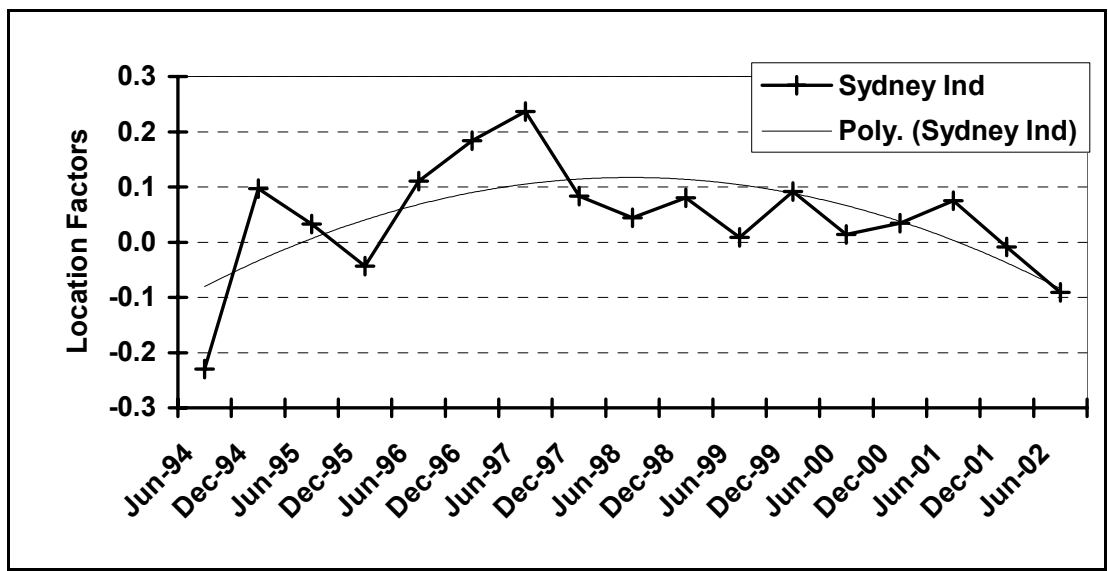

Figure 5: Location factors (with a curve-linear trendline; poly) of Melbourne industrial property market: 1995 - 2002

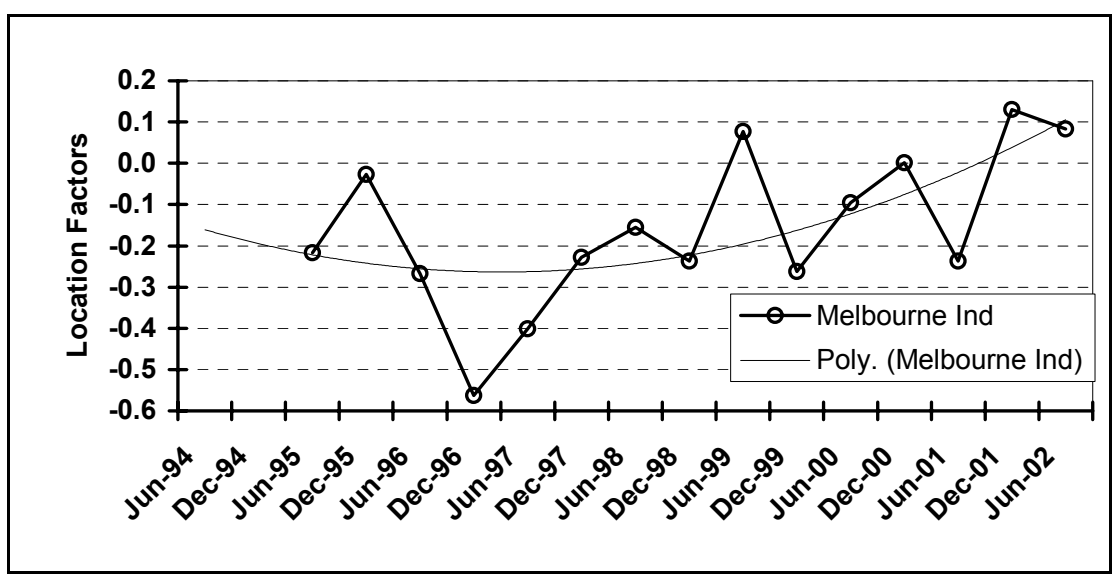


Figure 6: Location factors (with a curve-linear trendline; poly) of Brisbane industrial property market: 1994 - 2002

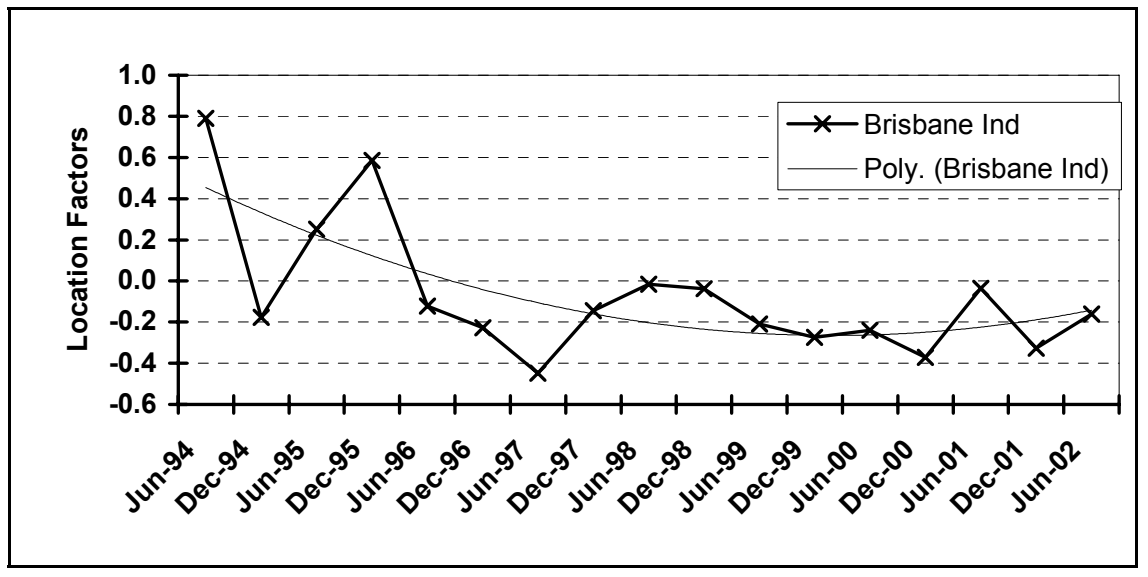

\section{CONCLUSION}

The investment performance (total returns) of the Australian industrial property market has significant correlations with the economic variables (positive correlations with CPI, GDP, and new capital expenditure on plant and equipment; negative correlation with interest rates). The Australian industrial property market was affected by positive economic factors during the study period $(1984-2002)$ except between 1990 and 1993. In terms of the sector specific economic factors, the Australian industrial property market was influenced by positive factors from 1991 to 2002. However, the sector specific economic factors of Australian industrial property market started to decline after more than 10 years positive growth. The Sydney industrial property market was under positive location factors from 1995 to 2000 and was under negative location factors from 2001. The Melbourne industrial property market was under negative location factors since 1994 to 2000 and started to grow with positive location factors from 2001. The Brisbane industrial property market shows a sharp decline in the location factors from 1994 and was under the influence of negative location factors after 1996. Therefore, investors should be careful before investing in the Australian industrial properties, as the sector specific economic factors have started to decline. However, the Melbourne industrial property market could still be considered a growing market. 


\section{REFERENCES}

Barras, R. (1994), 'Property and the Economic Cycle: Building Cycles Revisited'. Journal of Property Research, Vol.11, No.3, pp.183-197.

Barrett, G. and Blair, J. (1988), 'How to Conduct and Analyse Real Estate Market and Feasibility Studies'. New York: Van Nostrand Reinhold.

Baum, A. (1991), 'Property Investment Depreciation and Obsolescence'. London: Routledge.

Boykin, J. and Ring, A. (1993), 'The Valuation of Real Estate' (4th ed.). New Jersey: Regent/ Prentice Hall.

Darlow, C. (ed.) (1983), 'Valuation and Investment Appraisal'. London: The Estates Gazette Limited.

Jaffe, A. and Sirmans, C. (1989), 'Fundamentals of Real Estate Investment' (2nd ed.). New Jersey: Prentice Hall.

Keogh, G. (1994), 'Use and Investment Markets in British Real Estate’. Journal of Property Valuation \& Investment, Vol.12, No.4, pp.58-72.

Khalid, G. (1994), 'Obsolescence in Hedonic Price Estimation of the Financial Impact of Commercial Office Buildings: the Case of Kuala Lumpur'. Construction Management and Economics, Vol.12, pp.37-44.

McTaggart, D., Findlay, C. and Parkin, M. (1992), 'Economics'. Sydney: Addison-Wesley Publishing Company.

Property Council of Australia. (2002), 'Investment Performance Index'. PCA, June 2002.

Salway, F. (1986), 'Depreciation of Commercial Property'. Reading: College of Estate Management.

Vandell, K. and Lane, J. (1989), 'The Economics of Architecture and Urban Design: Some Preliminary Findings'. Journal of the American Real Estate and Urban Economics Association, Vol.17, No.2, pp.235-260.

Wofford, L. (1983), ‘Real Estate’ (revised ed.). New York: John Wiley \& Sons. 